\title{
Microstructure analysis of lower bainite
}

\author{
Smati Chupatanakul, Dajun Chen and Philip Nash \\ Thermal Processing Technology Center \\ IIT, $10 \mathrm{~W} 32^{\text {nd }}$ St., Chicago, IL 60616, USA
}

\begin{abstract}
:
The microstructure of lower bainite in 4317 type steels has been studied using optical microscopy and SEM. A lower bainite structure was produced by austempering. The nucleation and growth of lower bainite were analyzed at the beginning of the bainite transformation. At the same austempering temperature, the microstructures were analyzed for different austempering holding times, i.e. different bainite formation fraction. The results are compared to dilatometry results for each austempering temperature and austempering holding time in order to better understand the bainite phase transformation mechanism.
\end{abstract}

